\title{
VIAGEM PELOS CARNAVAIS EM PORTUGAL
}

\author{
Teresa Perdigão \\ (Instituto de Estudos de Literatura Tradicional \\ Universidade Nova de Lisboa)
}

O ciclo de festividades da Primavera incide na celebração do regresso do Sol e no forte desejo de renovação da função reprodutora e fertilizadora da Terra. Essas práticas expressavam-se em manifestações transgressoras da ordem estabelecida e em atos de purificação e de favorecimento da fertilidade, em ambiente alegre e licencioso.

CARNAVAL EM PORTUGAL, ORIGENS CARNAVAL, MÁSCARAS, FESTIVIDADES CARNAVAL, CALENDÁRIO RURAL. 


\section{TEMPO DE FESTA}

A vida são dois dias, o carnaval, três.

(dito popular)

O maior número de festividades sagradas concentra-se junto aos solstícios e aos equinócios. Essas festividades contêm memórias das crenças que Ihes deram origem e que estão essencialmente ligadas à agricultura e à relação do homem com a natureza.

No momento em que a terra é preparada para as sementeiras, o carnaval impõese como festa e ruptura do quotidiano não só em Portugal, mas em toda a cultura europeia, inserindo-se num sistema arcaico de hábitos e costumes de tradição religiosa.

Carnaval, Inverno e Primavera andam juntos em seu significado mais profundo.

Podemos dizer que o carnaval começa quando o Natal acaba. Depois dos festejos do solstício de Inverno, depois do ciclo da Epifania, a 6 de janeiro, e da Candelária, a 2 de fevereiro, iniciam-se os festejos, a 3 de fevereiro, dia de São Brás.

Seis de janeiro, dia do antigo ano novo para ao católicos ortodoxos, fecha o ciclo dos 12 dias, contados a partir do Natal, assegurando o recolhimento dos espíritos ctônicos e maléficos, com rituais, outrora comuns, como a bênção das águas, sinal de renovação da natureza e desejo de prosperidade.

\section{CARACTERÍSTICAS GERAIS DO CARNAVAL EM PORTUGAL}

Para a generalidade dos portugueses, carnaval é período de licenciosidade, bailes, foliões, cortejos, máscaras e mascarados. Corre-se de baile em baile, fazem-se os clássicos assaltos - entra um grupo mascarado em nossa casa, faz desacatos, come,

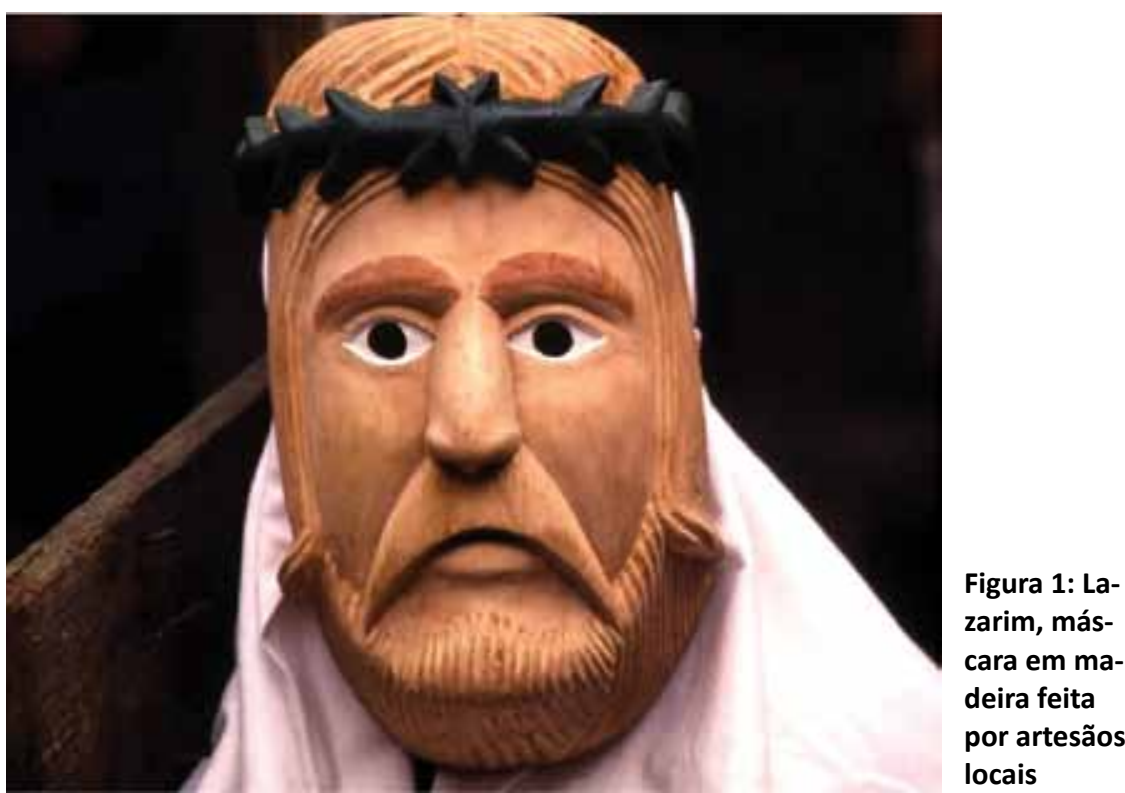


bebe, e, ainda por cima, corremos o risco de não saber quem lá entrou porque nunca tira a máscara. Mas nada parece mal. É carnaval.

Também para a generalidade dos portugueses oriundos de meio rural e com mais de 40 anos, o termo carnaval é de uso recente, pois o mais adequado era entrudo, terminologia mais antiga, usada pela primeira vez em 1252, com o significado de entrada. Os que viveram o entrudo aldeão recordam suas terras em alvoroço, plenas de algazarras, de rapazes e raparigas transvestidos, elas de rapazes, eles de raparigas, disformes e sempre exagerados.

A cidade era mais pacata, com alguns bailes ousados, mas compostos, até o momento em que o entrudo começou a invadi-la. Havia, pois, dois tipos de manifestações que hoje se confundem e não se distinguem. É de notar, porém, que algumas localidades com características eminentemente rurais, mantiveram suas distinções próprias, como veremos adiante.

As máscaras eram feitas de esborratadelas de carvão,

1 Agradeço a Afonso Almais tarde substituídas pelo papelão e, mais tarde ainda, pelas meias de vidro já usadas, até que o plástico quase invadiu o ves e a Hélder Ferreira a mundo carnavalesco, exceção feita sobretudo a sítios como Lacedência das fotografias. zarim, Podence e Vale d'Ilhavo, onde as máscaras são feitas de madeira, de lata ou de tecidos e penas de aves (figuras 1 e 2). ${ }^{1}$

Na região de Trás-osMontes (Terras Quentes), como Torre de D. Chama (Mirandela), porém, a máscara não é exclusiva do carnaval, e, por conseguinte, a associação desses dois elementos não se faz sempre com evidência. Também em Varge, Aveleda ou Bemposta (Trás-osMontes) as máscaras estão muito mais relacionadas com o Natal (Figura 3).

Figura 2: Podence, máscara em lata feita por artesãos locais

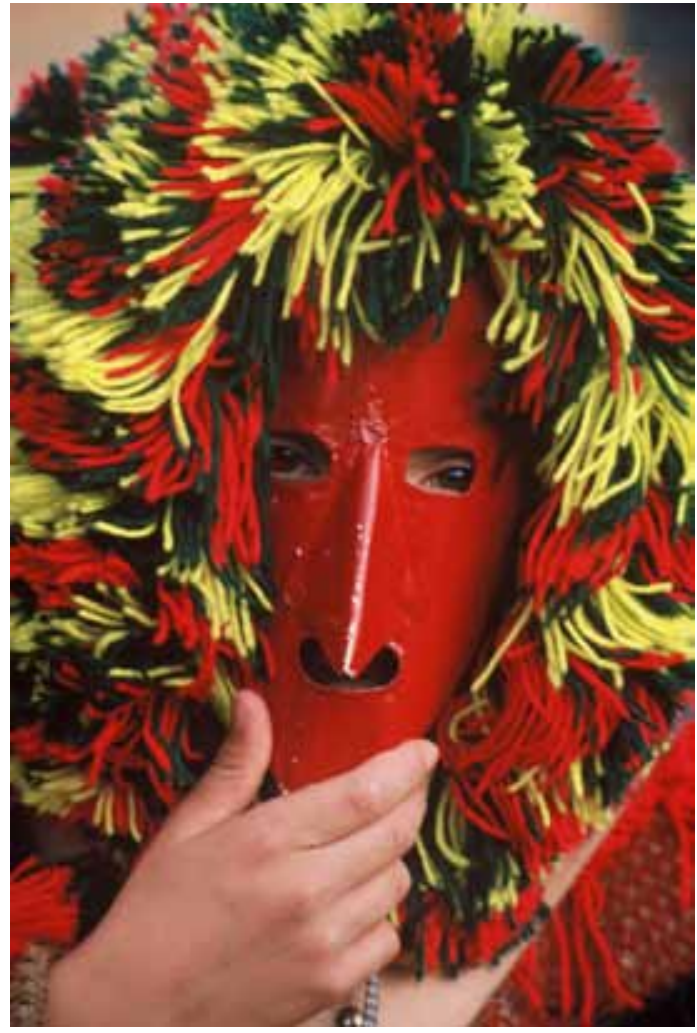




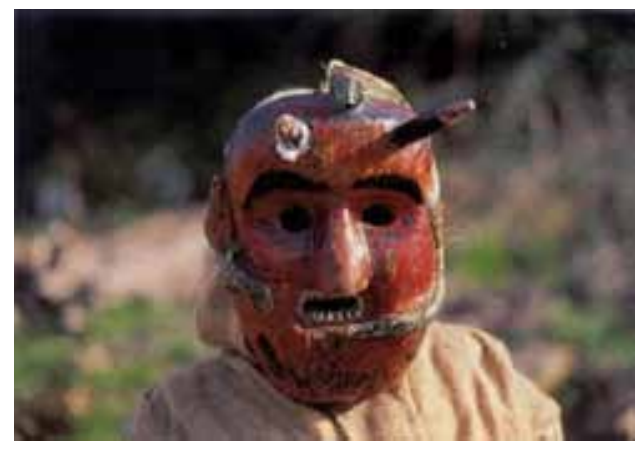

Figura 3: Máscara usada no Natal

Ora, o carnaval não existe sem máscaras, mas a máscara existe fora do tempo de carnaval, e não só em Portugal, mas, por exemplo, em Londres, no famoso Carnaval de Notting Hill, em agosto. Em toda a Europa se prestava culto aos mortos em novembro e usavam-se máscaras. Em Portugal, há mesmo um santo, São Mateus (Soure, Coimbra), que se cultua, em setembro, às vezes, com máscaras.

Já em Lazarim, no Douro, carnaval é máscaras, licenciosidade, ajuste de contas com a comunidade e refeições rituais. Ninguém se livra de ser mencionado em praça pública por aquilo a que chamam os testamentos das comadres ou dos compadres. Em Podence, a mesma coisa.

Mas em Repezes, perto de Viseu, o carnaval é marcado por desfile noturno, que é simultaneamente enterro e apresentação de reivindicações à Câmara de Viseu - deslocam-se a pé e, finalmente, queima-se o caixão (Figura 4). Em Cabanas de Viriato, a terra do cônsul Aristides Sousa Mendes, nas contradanças chamadas danças dos cus, os gigantones ajudam a festa (Figura 5).

Nas Beiras temos os roubos rituais. No Ribatejo e Alentejo encontramos as rusgas, as danças do mastro e os jogos do cântaro ou do galo, tudo isso entremeado com crítica social e política.

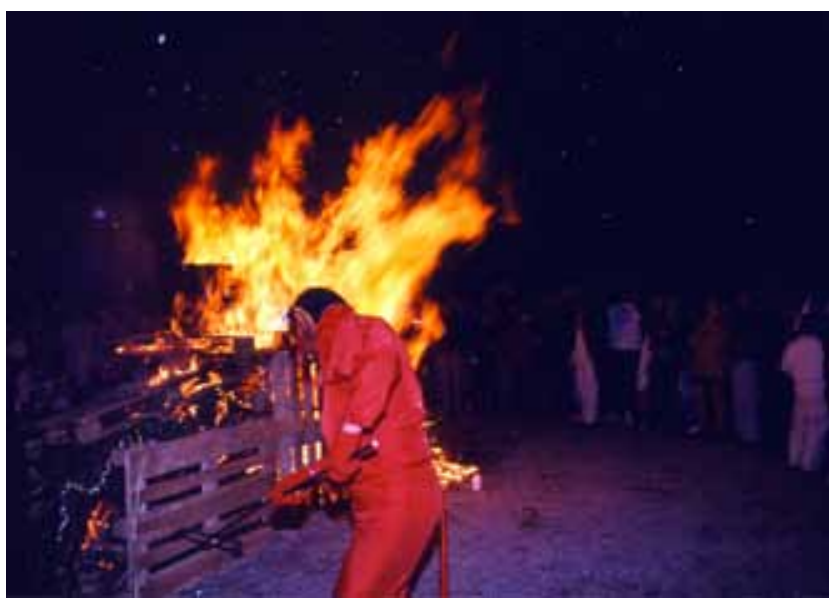

Figura 4: Repezes (Viseu), queima do caixão 
Atualmente temos eco dos grandes corsos carnavalescos: Ovar, Sesimbra, MeaIhada, Loulé e Torres Vedras. Nesses desfiles o que é mais marcante é o rei ou a rainha da festa, eleitos, designados ou, pura e simplesmente contratados e pagos para desfilar, o que contribui para atrair multidões, sobretudo quando se trata de figuras conhecidas da televisão. Essa prática é uma inversão das raízes, em que se inserem as tradições carnavalescas europeias, como veremos, o que, no entanto, nada contribui para lhes retirar brilhantismo e apoteose.

Assistimos também a uma prática recente que se generaliza: as escolas organizam desfiles pelas vilas e cidades, institucionalizando o que antes era espontâneo. Mas também isso não interfere, de modo nenhum, na compreensão do carnaval, antes contribui para sua manutenção ou, melhor, para certa evolução e transformação, características que também fazem parte da festa, posto que ela é imutável, mas também não obedece a uma lógica cartesiana. Elas variam, modificam-se, adaptam-se e organizam-se diferentemente, segundo o tempo e o lugar. Por isso, quando analisamos uma festa encontramos algumas práticas comuns a outras que se fazem na mesma época, mas também acontece que sobre elas se colam costumes que pertencem a outros momentos festivos. Por outro lado, há pequenos acontecimentos locais que alteram as festas e que tanto Ihes podem dar um empurrão como contribuir para seu retrocesso. Diga-se, a título de exemplo, que aconteceu quando os emigrantes, regressados a suas terras, queriam ver a festa como antigamente ou, endinheirados, se sentiam com poder e competência para as alterar. Aconteceu também quando eruditos intervinham no sentido de tornar a festa, segundo suas palavras, "mais característica e genuína". Esse caminho é atualmente seguido por jovens empenhados em fazer renascer a tradição, procurando acentuar o valor e a dignidade de sua terra.

Apesar da evolução e transformação operadas ao longo de centenas e milhares de anos, as festividades contêm ainda memórias das crenças e de práticas que lhes deram origem e que estão essencialmente ligadas ao calendário agrícola e à relação do ho-

Figura 5: Cabanas de Viriato, contradança ou dança dos cus

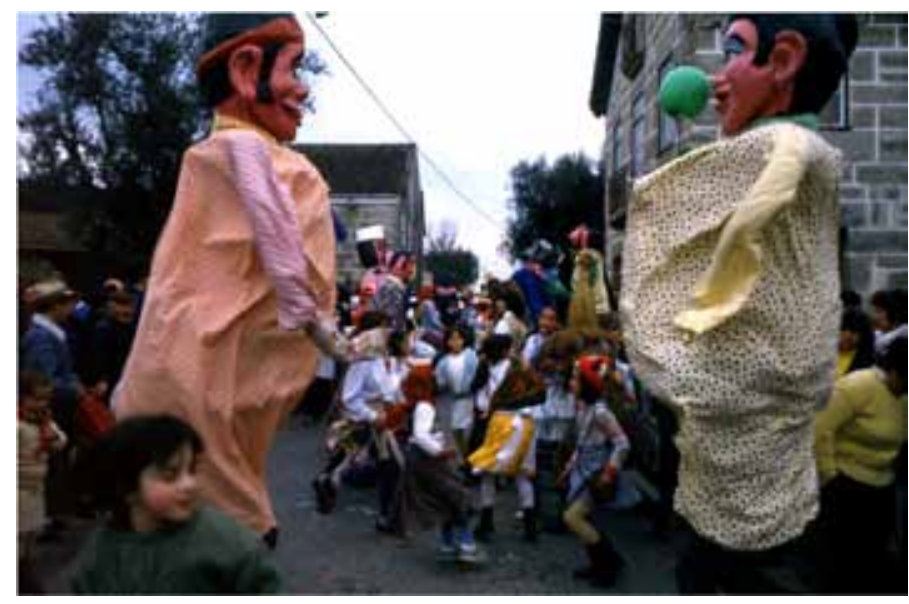


mem com a natureza, conforme já foi dito, mas que é importante reforçar. Mesmo que as mudanças lhes transformem o sentido, muitas vezes elas conservam apenas o aspecto plástico, sem seu significado. Veja-se o exemplo do rei e da rainha carnavalescos que ostentam básculo encimado pelo sol e pela lua, respectivamente (Figura 6).

Porém, apesar do que fica descrito, quer dizer, embora todas sofram a influência dos tempos e dos homens, dos hábitos, dos costumes e das modas, muitas mantêm tanto o sentido como o aspecto plástico muito fortes, dos quais se destacam algumas práticas: (1) desfilar com danças, contradanças e rusgas (Cabanas de Viriato, Vale d'Ilhavo); (2) usar mocas e paus (Podence, Lazarim); (3) bater nas raparigas, correr atrás delas, cardálas (Vale d'Ilhavo); (4) enfeitar carros de bois com alusão à Primavera e queimar um boneco chamado "Pai Velho" (Lindoso); (5) fazer barulho com chocalhos, campainhas, sinos, foguetes, bombinhas (Podence); (6) fazer testamentos em que impera a crítica social (Lazarim); (7) queimar bonecos de palha (Lazarim); (8) simular enterros (Repezes); (9) fazer ágapes opíparos (Lazarim); e (10) abusar de brincadeiras eróticas e de transvestidos.

\section{O CARNAVAL É SÃO BRÁS QUE O TRAZ}

Interpretar essas práticas e os resquícios que, às vezes, parecem exóticos e, enfim, compreender o carnaval é, no meu entender, começar por o situar no tempo.

Terminado o ciclo das festividades natalícias, em 2 de fevereiro, exatamente 40 dias após o Natal, inicia-se o ciclo do carnaval, com a festa de São Brás, em 3 de fevereiro.

É o início do final do Inverno e de um tempo de regozijo, em que se começa a sair da obscuridade e a entrar no período em que o sol propicia as sementeiras. Sai-se para os campos a fim de afastar os espíritos que, durante o Inverno, conviveram com os vivos ou os espíritos que teimam em ficar no reino dos vivos, em vez de descer aos subterrâneos da Terra, que é o seu lugar. Recordemos, a esse propósito, que o ciclo das festas de Inverno começa com a homenagem aos antepassados, nos dias $1^{\circ}$ e 2 de novembro.

Até aí decorreu o tempo em que a terra descansava, e o homem estava mais disponível. Só depois de terminado esse ciclo, se procurava acelerar a chegada da Primavera, com rituais que vêm de muito antes do Império Romano. Dessas práticas ainda temos resquícios em toda a Europa. Sabemos que os germânicos, os celtas e os eslavos eram povos que se regozijavam particularmente com o renascer da natureza. Essas festas ou manifestações, no mundo católico, tornaram-se rituais de purificação, expressos atualmente na Candelária (em 2 de fevereiro), na Quarta-feira de Cinzas e na quinta-feira da terceira semana da Quaresma. Antigamente, pela altura da Candelária, faziam-se expressamente refeições com grãos, comiam-se romãs e ovos - todos esses elementos ligados ao renascimento e à fertilidade. Esse hábito perdura no México, por exemplo, onde se comem tamales, feitas com grãos de milho. Em Portugal ainda há famílias que não passam esse dia sem abrir uma romã ou fazer frituras em azeite, também esse ingrediente, sumamente ligado à luz e ao sol, pois que esse dia também se designa por dia de Nossa 
Figura 6: Gaeiras (Óbidos), o sol e a lua, símbolos do ciclo das estações do ano

Senhora da Luz e situa-se precisamente no tempo que medeia o solstício de Inverno e o equinócio da Primavera.

Na França fazem-se crepes em 2 de fevereiro e come-se o molho aïoli feito à base de azeite. Num de seus departamentos, a Provence, o aïoli é prato emblemático, sempre presente nas grandes oca-

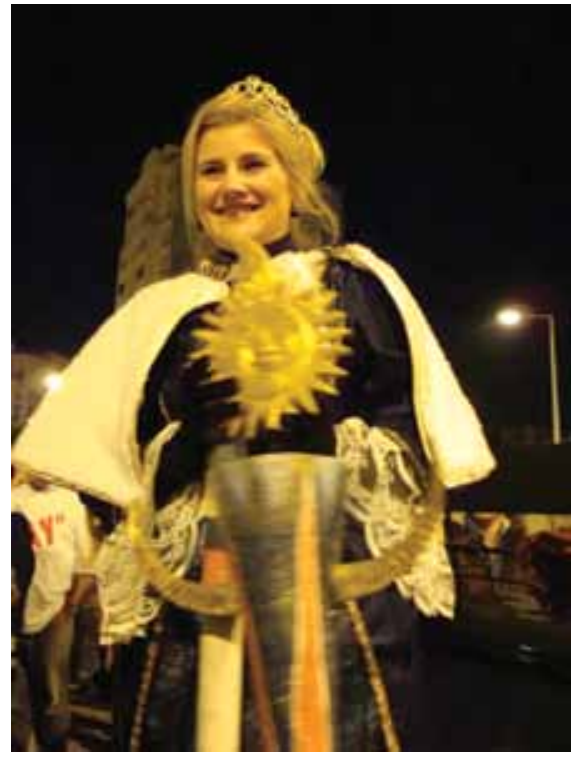
siões. É o prato que se consome quando da festa do azeite novo, no primeiro domingo de fevereiro. Depois da missa e depois da oferta de azeite à igreja, as pessoas comem tradicionalmente um prato de peixe cozido com ovos e legumes, dos quais fazem parte grãode-bico, com o referido molho de aïoli.

Todos esses festejos equivaliam a uma fórmula de agradecimento, como se se entregassem as primícias ao campo que nos alimenta e ao mesmo tempo lhe pedissem para no próximo ano ser, de novo, fértil e profícuo.

Reforçando-se sua antiga ligação com o tempo agrícola, note-se que era o momento em que se preparava a terra para as sementeiras de Primavera. Em Roma, era o tempo das Lupercálias - purificação ritual, na qual um animal era sacrificado, e com sua pele se faziam chicotes que os rapazes usavam para açoitar outros. Também no antigo Egito se festejava em 2 de fevereiro o nascimento da deusa Nut, mãe do deus-sol Ra.

Tanto a Senhora das Candeias ou da Purificação como São Brás são ainda hoje marcos do tempo. Vejamos:

Se a Senhora das Candeias chora, está o Inverno fora;

Se a Senhora das Candeias ri e chora, está o Inverno meio fora;

Se a Senhora das Candeias rir, está o Inverno para vir.

Segundo a crença popular, um animal - por exemplo, o urso ou a marmota - sai da hibernação nesse dia e, se o tempo chora, ele volta para seu abrigo, onde fica mais 40 dias. Se o tempo então permitir, o animal sai definitivamente e anuncia a Primavera. Ainda hoje, nos Pireneus se faz a caça ao urso e se executam danças, nos campos.

Esse dia marca também uma festa céltica ancestral, o imbolc - era a purificação do final do Inverno, atualmente cristianizada pela homenagem a Santa Brígida que, se- 


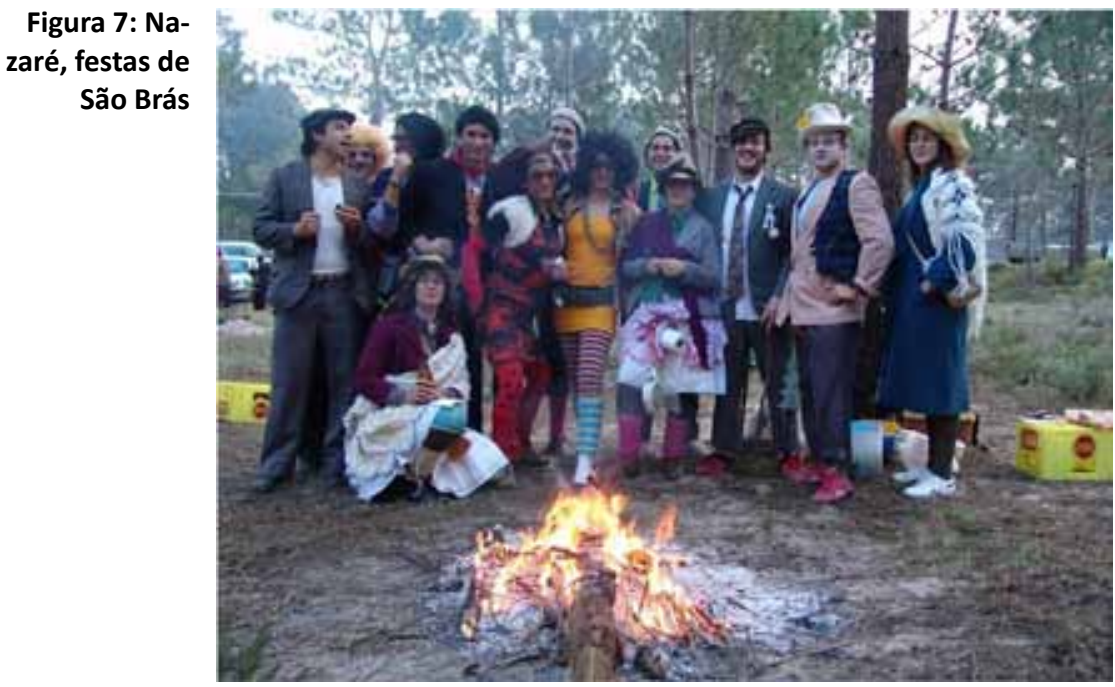

gundo a hagiografia, era pastora e leiteira. Lembremos que muitos dos rituais europeus, marcam nesse dia o regresso do leite das ovelhas que se aprontam para parir.

Ainda em busca de compreender o carnaval, situando-o no tempo, não posso deixar de referir o mito grego de Demeter e Perséfone, e os mistérios de Eleusis, que resumo rapidamente.

Perséfone, filha de Demeter, deusa da terra cultivada, foi roubada por Hades, deus dos infernos. Demeter não parou enquanto não encontrou Perséfone para a levar consigo para o Olimpo. Hades, influenciado por Zeus, remeteu-a à mãe, mas não sem antes Ihe ter dado as sementes da romã, o que fez com que Perséfone ficasse a viver dois terços do ano com Demeter e um terço com Hades.

Perséfone regressava à Terra com a chegada da Primavera. Esse acontecimento era celebrado sempre com grandes festas e rituais ligados à fertilidade.

Se na antiga Grécia se festejava o regresso de Perséfone, se na Europa se acredita no urso que sai da caverna, hoje a festa de São Brás é um sincretismo dessas práticas. Recordemos o aforismo que nos confirma a ligação estreita entre São Brás e a natureza:

No dia de São Brás, olha o Inverno que faz.

Se está para a frente ou se está para trás.

Também se relaciona São Brás com a chegada da cegonha, animal de bom augúrio, que anuncia os nascimentos, fertilidade e renovação, portanto. Por isso sua chegada era festejada em localidades fronteiriças, como Figueira de Castelo Rodrigo, Algôdres, Mata Lobos e Almofala: o rapaz que tivesse a ventura de primeiro ver a cegonha recebia uma gratificação e subia à torre e tocava o sino em sinal de regozijo.

Atestando sua ligação ao campo e à natureza, São Brás é festejado preferencialmente em bosques e pinhais. Protetor dos pastores, senhor das chuvas e das águas, ele também preside às sementeiras da Primavera. A muitos de seus festejos estão associadas 
práticas hoje consideradas obscenas, mas também se festeja com piqueniques, máscaras, exageros e fogueiras em Nazaré e em muitas outras localidades portuguesas, como Trancoso, Vila Real e Resende.

Quem desprevenidamente passar por Nazaré, pelo monte de São Brás, deparase, nesse dia, com um carnaval, antecipado, em que nazarenos e nazarenas usam máscaras, como se se tratasse da terça-feira de carnaval, fazem tropelias e comem chouriço assado em volta das inúmeras fogueiras que, nesse dia, povoam o pinhal. Só à noitinha se despedem e regressam a Nazaré, onde se faz um dos quatro bailes obrigatórios antes da terça-feira gorda (Figura 7).

Há anos, porém, em que o carnaval quase não deixa que se festejem o Natal e a passagem de ano. O tempo entre eles é tão escasso, que se festejam em simultâneo, como em 2008, em que o primeiro baile de carnaval se fez antes do Natal de 2007 e em que o dia de carnaval, marcado para dia 5, fez com que se antecipassem os festejos de São Brás para o sábado, dia 2 de fevereiro, de modo a realizar, na vila, os festejos carnavalescos habituais. $^{2}$

Como se trata de festa móvel, dependente do calendário lunar, ela se interpenetra com outras manifestações que estão,

2 Note-se que é obrigatório fazer um baile em cada final de semana que antecede o carnaval, no total de quatro, de preferência a partir do dia de São Brás. Só em anos excepcionais, como 2008, os bailes começam pelo $\mathrm{Na}$ tal, o que faz coincidirem os dois ciclos festivos. desde a cristianização, circunscritas às festas de Inverno. Através desse singular exemplo, nos apercebemos da dificuldade de classificar as festas por épocas ou rituais. Van Gennep (1947), porém, distinguiu, em meados do século XX, três categorias de cerimônias periódicas, inserindo o carnaval nas cíclicas, que se praticam em períodos mais ou menos longos, correspondendo aproximadamente às estações do ano, inserindo-o no ciclo do final do Inverno, o que contribuiu para melhor entendimento desses rituais.

O carnaval está, pois, delimitado no tempo e é celebrado com características e manifestações comuns em várias partes da Europa, com a inversão da lógica do quotidiano.

\section{PRIMAVERA, FERTILIDADE E RITUAIS DE RENOVAÇÃO}

Nesse sistema arcaico de rituais em que todos eles estavam interligados, lógica hoje perdida, a Primavera constitui o núcleo central, devido às atividades agrícolas de preparação das sementeiras e que abrangem, muito particularmente, rituais de purificação e de fertilidade da terra e do ser humano. Eles estão intrinsecamente ligados a um tempo em que se acreditava que o homem influenciava a natureza tornando-a mais fértil, desde que estivesse ele próprio puro (COSTA, 2007b), daí a prática de rituais de purificação que se manifestam através do sacrifício, da privação de certos alimentos e da abstinência sexual, incindindo as celebrações carnavalescas que as antecedem precisamente sobre o excesso e a licenciosidade. 
Preparar a terra significava praticar junto dela atos propiciatórios a sua fertilização, incitando-a a renascer. Vejamos, alguns rituais de incitamento à fertilidade, sem perder nosso rumo.

Ora, relatos mais tarde coligidos em livro e imagens comprovam a existência desses rituais tanto na Grécia e Roma antigas, como na Sibéria, na Escandinávia, na Europa Central ou do sul. Alguns investigadores já encontraram práticas comuns na antiga Babilônia. O mais importante será analisar os resquícios que ainda vigoram desses antigos rituais e compreender que o carnaval se insere num sistema de práticas comuns a toda a Europa, com um mesmo tronco, do qual derivaram diferentes manifestações.

\section{PRÁTICAS DE FERTILIDADE EM VALE D'ILHAVO (ILHAVO, AVEIRO), PODENCE (MACEDO DE CAVALEIROS) E LAZARIM (LAMEGO)}

Um dos rituais mais complexos e completos desta época é o de Vale d'Ilhavo, em que os rapazes durante várias finais de semana se refugiam secretamente no que eles chamam de caserna, preparando-se para no dia de carnaval sair à rua e 'cardar' as raparigas, batendo-Ihes com escovas de madeira e enfiando seus narizes fálicos onde conseguem, enquanto elas fogem.

Esses rapazes saem transmutados em seres aparentemente andróginos, com fatos de renda, tipo roupa interior e com belíssima máscara, integralmente feita por eles (Figura 8).

Prática semelhante existe em Podence, onde os rapazes batem violentamente com guizos nas ancas das raparigas. Nesses rituais de anúncio da Primavera, faziamse danças eróticas, praticavam-se atos obscenos e ditos menos aceitáveis, para facilitar a germinação, procurando passar a energia das pessoas para as plantas. Atualmente ainda há localidades que incorporam um boi no cortejo, como forma de manifestar a virilidade reprodutiva e fertilizadora.

Muitas danças atuais não são mais do que essa forma antiga de fazer apelo à fertilidade. São o símbolo da força viril reprodutiva.

As atuais festas carnavalescas atestam as memórias dessas práticas, através do nudismo, do riso e do frenesi que cria o clima de erotismo.

Ainda no sentido de demonstrar que o homem é elemento propiciador de purificação, era comum condenar os infratores às regras sociais estabelecidas ou, muito frequentemente, eleger um bode expiatório.

As práticas de crítica social e de culpabilização dos infratores estão expressas nos testamentos que se fazem em Lazarim, por exemplo, ou em Podence. Expiam-se os males expondo-os publicamente. A prática católica reside na confissão obrigatória e na comunhão, o que representa, de igual modo, a purificação.

O conceito do bode expiatório, presente no Antigo Testamento, segundo o qual um bode assumia as culpas dos cidadãos e era escorraçado da cidade para os libertar das 
Figura 8: Vale d'Ilhavo, rapaz com máscara fálica e as cardas nas mãos

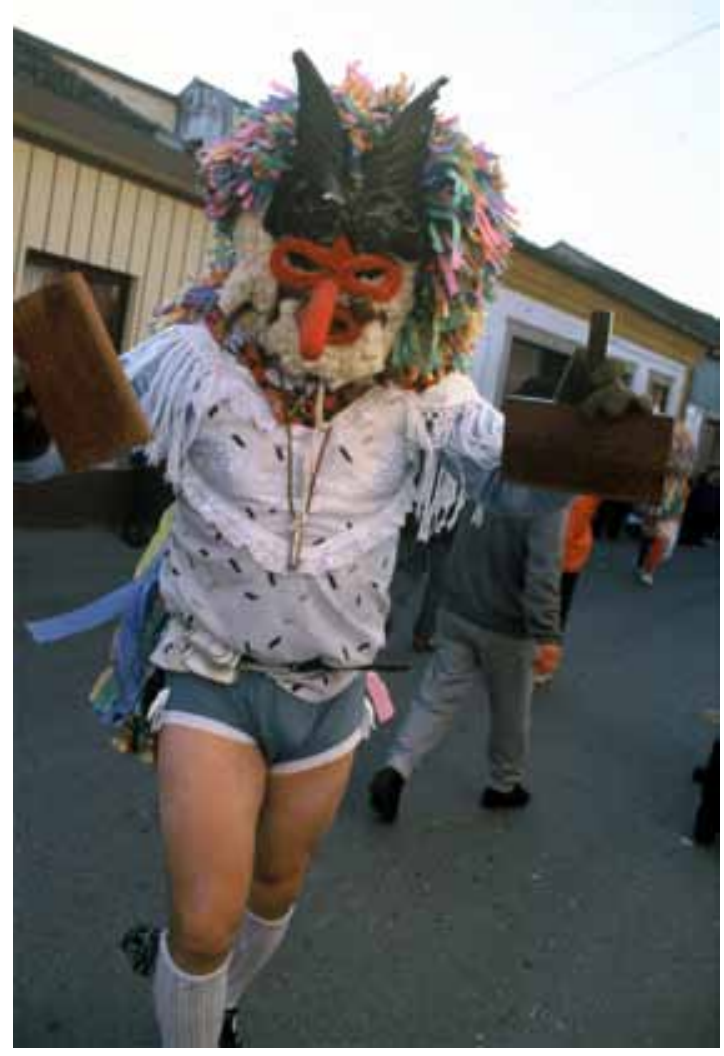

faltas cometidas, existia na Grécia. Aí havia o costume de, a expensas da cidade, se alimentar um mendigo (ou um prisioneiro, ou um deficiente) durante um ano (às vezes, em caso de uma praga, dada a urgência, era o que estivesse mais à mão...), para que, então, em cerimônia fosse coberto por roupas solenes e percorresse a cidade, de modo a atrair para si todos os problemas: fome, doenças, crimes. No final era lapidado até a morte. Em algumas cidades era atirado do alto de um precipício. Em outras, era apedrejado, mas podia fugir se sobrevivesse... Posteriormente, escolhia-se um escravo para ser chicoteado e expulso, concedendo-lhe, em consequência, a liberdade.

$\mathrm{Na}$ base da descoberta de um bode expiatório que assumisse os males e os desregramentos da sociedade, encontramos resquícios como a serração da velha e a eleição de reis e rainhas, prática que se vem tornando comum, sobretudo no mundo urbano. Eles representavam o Inverno, os maus espíritos e tudo o que pudesse ameaçar a estabilidade da sociedade.

Faziam-se bonecas de palha que se queimavam, nos campos, muitas vezes, em honra de Santa Brígida ou de deusas da fertilidade, propiciando a regeneração dos campos e, naturalmente, dos homens também. Purificação, fertilidade e renovação eram conceitos que andavam de par e que se confundiam entre si. 


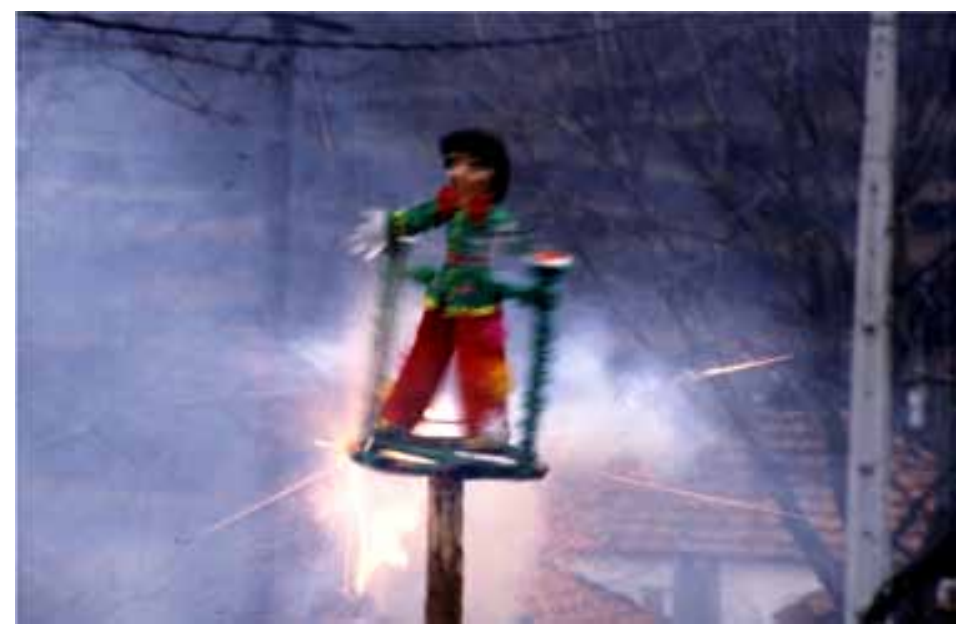

Figura 9:

Queima dos compadres

Em Lazarim, no dia de carnaval, depois do testamento público, o cortejo vai para o campo a fim de queimar os antropomorfos bonecos, designados por comadre e compadre (figuras 9 e 10), cujas cinzas ficam, simbolicamente, em terreno cultivado, como garantia da fecundação da terra e da sobrevivência da comunidade.

Esses ritos mágico-agrários, executados em ambiente alegre e licencioso, tinham por objetivo favorecer a fertilidade da terra e a multiplicação de todos os seres vivos, e conjugavam-se com os rituais purificadores que pretendiam afastar o Inverno.

O carnaval está também relacionado com práticas crematórias, bem expressas na famosa lenda da Manekine, escrita por Phillippe Remy, no século XIII e que conta a história da jovem Joie, cujo pai, rei húngaro, desejava casar-se com ela. Perante tal afronta, ela mutila a própria mão esquerda como forma de mostrar seu desagrado e repulsa por tal desejo, apesar de ele visar ao cumprimento da promessa que o pai fizera à mãe moribunda - de jamais se casar com mulher menos bela do que ela. A única mulher nessa condição era a própria filha, Joie. Por duas vezes condenada à fogueira, Joie, depois chamada Manequine, sempre conseguiu escapar, salva pelos próprios carrascos. Note-se que 2 de fevereiro é o dia em que o rei quer casar-se com a filha que, depois de enviada à deriva rio abaixo, chega à Escócia no primeiro domingo a seguir ao carnaval e casa com o rei no dia de Pentecostes e dois anos mais tarde, em janeiro, dá à luz o primeiro filho. Tratandose de narrativa que traduz o mito do carnaval, ela nos dá conta das características de fertilidade e germinação a que estavam adstritos os rituais da época, bem como os de cremação dos quais ainda hoje há resquícios, tanto nas fogueiras que se fazem no dia de São Brás como nos gigantones que aparecem nos corsos ou na cremação de simulacros de defuntos, como acontece em Repezes.

Como dissemos, o carnaval decorre da observância das estações do ano e do desejo de acabar com o Inverno, substituindo-o pela Primavera. Por conseguinte, o carnaval 


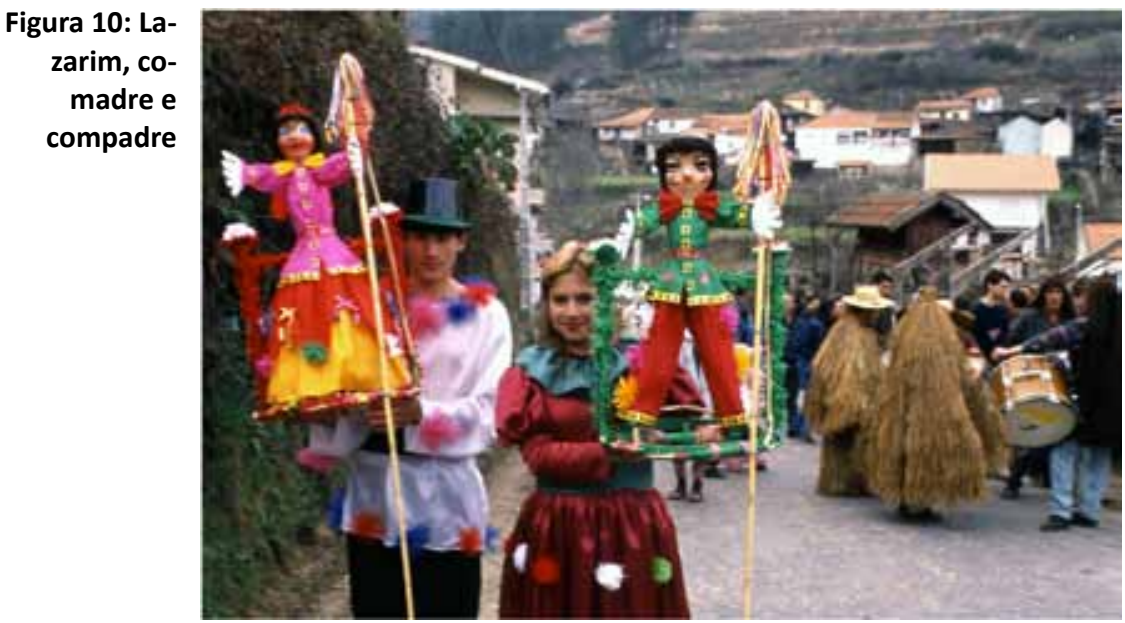

emerge numa série de costumes ancestrais, inseridos nas festas de Inverno e no calendário que organiza o ano segundo as fases lunares.

Muitos resquícios desses rituais permanecem hoje, num tempo que nada tem a ver com o que outrora anunciava e propiciava a fertilidade da terra, e que, consequente e obviamente, foram perdendo sentido, o que não impede que a festa continue a cumprir a função de ruptura com o quotidiano, de convívio e de renovação, incluindo o meio urbano.

E, porque as festas, embora tenham raízes ancestrais, se transformam, termino com uma ideia que devo a Domingos Morais: Mesmo sabendo que a tradição "já não era o que é, nem será o que foi e nunca foi o que pensávamos que era", cada geração inventa, recria, adapta, adota e copia, sem culpa nem pecado.

\section{REFERÊNCIAS BIBLIOGRÁFICAS}

COSTA, Antonieta. Azorean Carnival a parallel for other places and cases, 2007a (manuscrito).

COSTA, Antonieta. Mitologias agrárias, coerência e persistência, rituais açorianos ligados ao calendário cósmico, 2007b (manuscrito).

GENNEP, Arnold van. Manuel de Folklore Français Contemporain, Paris: J. Picard et Cie., 1947.

Teresa Perdigão é antropóloga, dedicando-se ao estudo de manifestações das comunidades, em contextos festivos e religiosos. Nessas áreas tem (co)realizado alguns documentários, como o Auto de Florípes na llha do Príncipe e Pico - A llha da Montanha. Tem publicados, entre artigos e outro livros, Portugal - festas e romarias; Tesouros do artesanato português (4 volumes); Máscaras em Portugal (coord.). 